\title{
PERAN GRASSROOT ACTOR TERHADAP POTENSI TINDAK PIDANA KORUPSI DALAM KEBIJAKAN BANTUAN PANGAN NON TUNAI (BPNT)
}

\author{
Gunawan \\ Magister Hukum Tindak Pidana Ekonomi, Universitas Sebelas Maret, Indonesia \\ J1. Ir Sutami No.36A, Jebres, Kec. Jebres, Kota Surakarta, Jawa Tengah 57126 \\ E-mail: gnw.wibisono.1973@gmail.com
}

\begin{abstract}
Non-Cash Food Assistance (BPNT), has the ability as an effort to protect the community (Social Defense) and an effort to achieve community welfare (Social Welfare). At the implementation stage of the program, the legal events summarize the tug of war of interests in accessing resources played by grassroot actors. This article identifies and formulates problems in the question, how is the role of grassroot actors as a potential criminogenous correlative factor for corruption in the implementation of the BPNT program? This study aims to analyze the potential for corruption in the BPNT program to arise from the sociological implications of its application in society. The research study used is a normative juridical approach in both broad and narrow terms. The results found in this study are the potential for corruption, stemming from the role of grassroot actors who have excessive power in power relations to gain access to BPNT resources (single supply of foodstuffs to E-Warong). The strengthening of the potential for corruption is boosted by the discretionary behavior of program supervisors. It takes proactivity in the role of program guard (Government) in terms of its implementation.
\end{abstract}

Keywords: Grassroot Actor, Discretion, Non-Cash Food Aid

\begin{abstract}
Abstrak
Bantuan Pangan Non-Tunai (BPNT), memiliki kemampuan sebagai upaya perlindungan masyarakat (Social Defence) dan upaya mencapai kesejahteraan masyarakat (Social Welfare). Pada tahap implementasi program, peristiwa hukumnya merangkum tarik menarik kepentingan dalam mengakses sumber daya yang dimainkan oleh grassroot actor (Aktor akar rumput). Makalah ini mengidentifikasi dan merumuskan problematika dalam pertanyaan bagaimanakah peran grassroot actor sebagai faktor korelatif kriminogen potensi tindak pidana korupsi pada implementasi program BPNT? Penelitian ini bertujuan menganalisis potensi timbulnya tindak pidana korupsi penyimpangan program BPNT bersumber dari sosiologis penerapannya di masyarakat. Kajian penelitian yang digunakan adalah pendekatan yuridis normatif baik dalam arti luas maupun sempit. Hasil yang ditemukan pada kajian ini ialah potensi timbulnya tindak pidana korupsi, bersumber dari peran aktor akar rumput (grassroot actor) yang memiliki excessive power dalam relasi kuasa mendapatkan akses sumber daya BPNT (pasokan tunggal bahan pangan ke E-Warong). Penguatan potensi tindak pidana korupsi dibooster oleh perilaku diskresi supervisor program. Dibutuhkan proaktivitas peran pengawal program (Pemerintah) dalam hal implementasinya.
\end{abstract}

Kata Kunci : Grassroot Actor, Diskresi, Bantuan Pangan Non-Tunai 


\section{A. Pendahuluan}

Setiap kebijakan pemerintah yang bertujuan memajukan kesejahteraan umum merupakan dambaan bagi kita semua. Kesejahteraan sosial merupakan amanat konstitusi yang terumuskan dalam pembukaan UUD 1945. Kenyataannya, Kementerian Keuangan (Kemenkeu) mencatat, sampai dengan 6 Mei 2020 realisasi penyaluran bantuan sosial (bansos) bantuan pangan nontunai (BPNT) kartu sembako mencapai Rp 14,16 triliun, atau 32,4\% dari total anggaran yang disiapkan sebesar Rp 43,6 triliun. ${ }^{1}$ Fakta ini tidak mengherankan karena program BPNT, merupakan program kelanjutan dari Rastra (Beras Sejahtera) yang bertransformasi menjadi BPNT dengan tujuan efisiensi penyerapan bantuan melalui 6T, yaitu tepat : sasaran, waktu, jumlah, kualitas, harga dan administrasi. Penyerapan anggaran pemerintah sebesar 30 an persen, menjadi problematika tersendiri dari pelaksanaan program BPNT ini.

Adapun program Rastra, yang diputuskan pemerintah sebelum masa pandemi Covid 19 , terlihat data sebagai berikut ${ }^{2}$ : dari data Bulog, penyaluran rastra-sebelum program BPNT digulirkan-rata-rata mencapai 2,7 juta ton per tahun. Dengan program bansos rastra, penyaluran beras dari Bulog pada tahun 2018 sebesar 1,21 juta ton dan pada tahun 2017 sebanyak 2,55 juta ton.

Mulai tahun anggaran 2017, penyaluran beras sejahtera (rastra) dilakukan melalui kupon elektronik (e-voucher). Kupon elektronik digunakan oleh penerima manfaat untuk membeli beras. Penyaluran bantuan pangan secara non tunai mulai dilakukan tahun 2017 di 44 kota. Mulai 2018, subsidi rastra juga dialihkan menjadi bansos. Pengalihan kebijakan bantuan sosial ini berdampak terhadap tantangan program kebijakan baru dari pemerintah yaitu program kebijakan BPNT (Bantuan Pangan Non-Tunai). Bulog sebagai pilar penyangga beras nasional, perannya mulai bergeser dan digantikan oleh stake holder penyalur atau pemasok bahan pangan dalam BPNT.

Bantuan Pangan Nontunai, yang selanjutnya disebut BPNT, adalah bantuan sosial pangan yang disalurkan dalam bentuk nontunai (uang elektronik) dari pemerintah kepada KPM setiap bulannya dan yang digunakan KPM hanya untuk membeli bahan pangan di e-Warong. Untuk daerah dengan akses terbatas, mekanisme pelaksanaan BPNT akan diatur lebih lanjut sesuai dengan kebijakan pemerintah ${ }^{3}$. Keluarga Penerima Manfaat, yang selanjutnya disebut dengan KPM, adalah keluarga yang ditetapkan sebagai penerima manfaat Program BPNT ${ }^{4}$. Program ini berlandaskan pada asas efisiensi dan peningkatan kontribusi keuangan inklusif.

Asas efisiensi, tepatnya efisiensi berkeadilan terumuskan original intensnya pada Pasal 33 Ayat (4) Undang-Undang Dasar 1945. Formulasi yuridisnya : "(4) Perekonomian nasional diselenggarakan berdasar atas demokrasi ekonomi dengan prinsip kebersamaan, efisiensi berkeadilan, berkelanjutan, berwawasan lingkungan, kemandirian, serta dengan menjaga keseimbangan kemajuan dan kesatuan ekonomi nasional'.

1 Rahma Anjaeni, “Kemenkeu Catat Realisasi Penyaluran BPNT Kartu Sembako Senilai Rp 14,16 Triliun,” 2020, https:// nasional.kontan.co.id/news/kemenkeu-catat-realisasi-penyaluran-bpnt-kartu-sembako-senilai-rp-1416-triliun.

2 Ferry Santoso, "Realisasi Penyaluran Bansos Rastra Turun," 2019, http://bulog.co.id/berita/37/6932/10/1/2019/RealisasiPenyaluran-Bansos-Rastra-Turun.html.

3 Tim Pengendali Pelaksanaan Penyaluran Bantuan Sosial Secara Non Tunai, Pedoman Umum Bantuan Pangan Nontunai 2019 (Jakarta Pusat: Kementerian Koordinator Bidang Pembangunan Manusia dan Kebudayaan, 2019), 7, https://www. kemsos.go.id/uploads/topics/15767284433221.pdf.

4 Ibid, 9. 
Penggabungan strategi kebijakan antara keuangan inklusif dan efisiensi penyaluran, merupakan kebijakan yang perlu diuji dalam tataran implementasinya. Apakah tujuan yang dicanangkan dalam kebijakan BPNT efektif pada tingkat pelaksanaannya? Sementara itu ruang publik yang menjadi ekosistem program BPNT berisi tantangan baik substansi hukum, struktur hukum maupun budaya hukum yang menjadi operasionalisasi program kebijakan.

Sementara itu, kebijakan ekonomi inklusif merupakan produk hukum turunan dari UUD 1945 berupa Perpres No 82 Tahun 2016 tentang Strategi Nasional Keuangan Inklusif. Mengacu kepada tertib hukum peraturan perundang-undangan, maka Perpres No 82 Tahun 2016 harus tegak lurus kepada norma yang lebih tinggi yaitu asas efisiensi berkeadilan yang tercantum dalam UUD 1945. Batasan pengertian keuangan inklusif adalah kondisi ketika setiap anggota masyarakat mempunyai akses terhadap berbagai layanan keuangan formal yang berkualitas secara tepat waktu, lancar, dan aman dengan biaya terjangkau sesuai dengan kebutuhan dan kemampuan dalam rangka meningkatkan kesejahteraan masyarakat ${ }^{5}$. Pengertian ini, memiliki konsekuensi hukum bahwa hanya dalam kondisi mencapai kesejahteraan masyarakat, kebijakan pemerintah membingkai setiap program kebijakan yang terkait domain publik. Dengan kata lain, setiap kebijakan yang terkait kepentingan masyarakat (publik) harus dalam kerangka kesejahteraan masyarakat. Termasuk di dalam nya adalah program Bantuan Pangan Non Tunai (BPNT).

Maka secara prinsip dasar BPNT berlandaskan pada dua pilar kokoh bernama efisiensi berkeadilan dan keuangan inklusif. Konstruksi perumusan kebijakan tersebut wajar karena niat awal pemerintah manapun selalu berbasis konstitusional yaitu menjadikan tujuan Negara Republik Indonesia dalam pembukaan UUD 1945 menjadi cita hukum penyelenggara Negara.

Fakta sosial menggambarkan tentang ketidaksesuaian antara cita-cita dalam BPNT dengan penerapan di ruang publik tercermin dari beberapa indikator. Salah satunya ialah dorongan pemerintah untuk menggerakan sektor ekonomi rakyat melalui sistem perbankan dalam penyaluran beras dan telur serta bentuk pemaketan barang (beras dan telur) pada implementasi program BPNT telah menyimpang dari tujuan semula.

Realitasnya, terdapat praktek monopoli pengadaan beras dan telur dalam BPNT, yang terjadi pada penerapan program di tingkat hilir. Yaitu ketika supplier beras dan telur ternyata hanya dipasok oleh satu pemasok tunggal, melalui proses transaksi dengan pihak regulator (Dinas Sosial). Lebih jelasnya problematika penyaluran BPNT, masih bernuansa kolusi dengan pihak pemasok kebutuhan beras dan telur dalam program BPNT itu. Sehingga permasalahan awal dalam makalah ini berangkat dari benturan kepentingan antara domain tata kelola (pemerintah) dan tata usaha (pengusaha atau pemasok). Irisan antara dua kepentingan tersebut, membawa konsekuensi penyimpangan dalam program BPNT.

Hukum menjadi sarana mengarahkan pencapaian setiap program pemerintah. Hal ini lazim karena basic idea Negara adalah berdasarkan hukum. Asimetris kebijakan BPNT pada ranah gagasan atau ide dengan pelaksanaan di masyarakat, menarik untuk dikaji lebih jauh pada bingkai perspektif sosiologis masyarakat yang beririsan dengan potensi tindak pidana korupsi. Karena pada program BPNT, didanai dari APBN Jo. Keuangan Negara. Dengan demikian imperative tindak pidana korupsi dalam penyimpangan keuangan Negara perlu

5 Peraturan Presiden Nomor 82 Tahun 2016. Strategi Nasional Keuangan Inklusif.. 
dikaji penyebab utama terhadap sumber inefiensi dan tindakan kejahatan atau ketercelaan dalam penyimpangan dana BPNT.

Hulu dari permasalahan utama dalam kajian ini bermula dari retakan dalam sub sistem pada struktur sosial BPNT yang hendak diterapkan dalam wilayah publik. Sebagai gambaran identifikasi awal dalam melihat permasalahan tersebut, dapat diuraikan sebagai berikut: struktur sosial baru dalam penerapan BPNT meliputi Keluarga Penerima Manfaat (KPM), Bank penyalur, E-Warong, Kementrian dan atau Kelembagaan Pemerintah, serta Masyarakat. Adapun mekanisme operasionalisasi masing-masing struktur sosial tersebut terangkai dalam payung hukum peraturan pemerintah, instruksi presiden, peraturan menteri hingga pedoman umum dan petunjuk teknis pelaksanaan BPNT. Di sisi lain, struktur budaya masyarakat telah mapan, dengan penerapan kebijakan pemerintah dalam bentuk bantuan tunai (bukan barang/pangan). Kontradiksi ini berimplikasi pada benturan kepentingan yang menghasilkan ketegangan-ketegangan baru dalam struktur sosial dan budaya masyarakat. Penguatan program ekonomi inklusif yang terukur, ke dalam tubuh kebijakan BPNT ini membawa konsekuensi adanya sub sistem e-money berupa pelibatan KPM dalam sistem perbankan.

Tantangan baru tersebut, membawa dampak terhadap perubahan struktur sosial dalam budaya mapan masyarakat yang telah terbiasa dengan bantuan tunai. Mereka tidak dihadapkan dengan kerumitan struktur sosial baru, yang menuntut adanya literasi perbankan dalam penyaluran bantuan non tunai. Pergeseran antara struktur sosial dengan struktur budaya masyarakat yang mengakar inilah, pintu problematika dalam implementasi kebijakan BPNT. Dinamika sosiologis masyarakat dalam beradaptasi terhadap perubahan kebijakan bantuan sosial pemerintah ini, menarik secara akademis karena menampilkan celah baru bagi bahan dan wawasan terhadap kajian sosiologis dalam kebijakan BPNT.

Makalah ini bertujuan menganalisis potensi timbulnya tindak pidana korupsi penyimpangan program BPNT bersumber dari sosiologis penerapan program di masyarakat. Metode kajian yang digunakan dalam merumuskan solusi terhadap masalah yang diangkat menggunakan yuridis normatif dalam arti yang luas dan sempit ${ }^{6}$. BPNT sebagai program pemerintah dalam upaya perlindungan sosial dan mencapai kesejahteraan sosial, mengandung kompleksitas variabel baik sosial, hukum, budaya maupun ekonomi. Keseluruhan variabel tersebut dapat dijelaskan dengan dua pola, yaitu pola sosiologis dan pola hukum. Pola sosiologis menerangkan bagaimana masyarakat merespons dan beradaptasi dengan adanya program BPNT. Sedangkan pola hukum mampu memetakan perlindungan norma keadilan ketika hukum berinteraksi dalam kehidupan sosial. Lensa sosiologis menjelaskan tentang potensi dan realisasi adaptasi aktor akar rumput (grassroot actor) dalam berperan mengakses sumber daya, sementara itu dimensi/pola hukum berkontribusi "mengawal" nilai keadilan yang menjadi inti kebermaknaan program BPNT.

Poin utama yang hendak dijelaskan makalah ini melalui optik sosiologis adalah faktor korelatif kriminogen (penyebab tindak pidana) pada program BPNT. Tahapan atau kondisi seperti apa yang melatarbelakangi pemicu penyimpangan dalam kategori potensi tindak pidana korupsi. Selain itu, menjelaskan pula teori Klitgaard tentang korupsi yaitu adanya monopoli plus diskresi minus akuntabilitas.

Makalah ini diharapkan mampu memberikan gagasan perspektif yuridis sosiologis terhadap penyimpangan program BPNT yang berimplikasi terhadap tindak pidana korupsi.

6 Sudarto, Hukum Dan Hukum Pidana (Bandung: Alumni, 1981). 


\section{B. Pembahasan}

Data kualitatif yang berhasil dihimpun menjadi peristiwa hukum dalam implementasi kebijakan BPNT di salah satu daerah penelitian, menjelaskan temuan sebagai berikut :

"Program Bantuan Pangan Non Tunai yang pelaksanaannya dimulai pada bulan Oktober 2018. Jumlah KPM berbasis data yang dikeluarkan oleh Pemerintah sebagai berikut : sebanyak 69.904 orang $^{7}$, berubah sebanyak 73.642 orang $^{8}$, sebanyak 71.215 orang $^{9}$ dan 71.248 orang $^{10}$. Adapun data KPM berbasis data dari Bank Panyalur Jumlah KPM berdasarkan topup kartu KKS sebagai berikut: 73.198 (Okt 2018), 73.198 (Nov 2018), 73.198 (Des 2018), 73.198 (Jan 2019), 67.250 ( Peb 2019), 67.250 (Mar 2019), 67.250 (April 2019), 71.004 (Mei 2019), 71.004 (Juni 2019), 71.004 (Juli 2019), 71.004 (Agt 2019) dan 71.004 KPM (Sept 2019). Realitas di lapangan, tidak seluruhnya kartu milik KPM tersebut bisa ditransaksikan, hanya rata-rata tiap bulannya jumlah KKS milik KPM yang aktif atau dapat bertransaksi hanya sebanyak 62.000 s.d 64.000, dikarenakan alasanalasan sebagai berikut:(a.) KKS ada yang belum terdistribusi;(b). KKS yang bermasalah (error);(c.) KKS hilang.

Bank Panyalur akhirnya meminta bantuan kepada Dinas Sosial dan PPKB Kab. setempat, untuk mengajukan calon e-warong, yang dalam pelaksanaannya melibatkan Kepala Desa setempat, sehingga didapat 407 e-warong yang dajukan oleh Dinas Sosial dan PPKB setempat, yang mendapat persetujuan BNI sebagai bank penyalur dan ditunjuk menjadi agen e-warong oleh BNI (memperoleh EDC) hanya 318 e-warong.

Pelaksanaannya 407 e-warong tersebut ternyata tetap beroperasi dan melayani KPM, sehingga yang belum memiliki EDC meminjam dari e-warong yang sudah memiliki EDC. Proses penunjukan e-warong ternyata tidak sepenuhnya memperhatikan ketentuan terkait harus sudah mempunyai usaha dagang (warung) sembako, namun ada beberapa e-warong yang tidak menjual sembako tetapi ditunjuk menjadi e-warong. Ternyata selain tidak memperhatikan ketentuan persyaratan pemilihan e-warong, baik pihak BNI maupun Dinsos PPKB juga tidak melakukan sosialisasi yang memadai kepada pihak e-warong, sehingga banyak e-warong yang kebingungan baik penggunaan EDC maupun bagaimana mendapatkan suplai sembako (beras maupun telur).

Akibatnya kondisi tersebut dimanfaatkan oleh pihak ketiga sebuah perkumpulan penggilingan padi. Actor yang terlibat adalah sdr. J (Kepala Desa A) dan sdr. DH (Kepala Desa B). Kedua actor tersebut diduga mendirikan perkumpulan penggilingan padi dalam rangka untuk memasok beras dan telur dalam program BPNT di Kab. Setempat.

Meski merupakan perkumpulan Penggiling Padi di Kab. setempat namun sejatinya perkumpulan tersebut, adalah representasi dari Sdr J dan DH saja, sedangkan Penggiling Padi lainnya adalah suppliyer yang mensuplay beras ke E-Warong yang harus melalui $S d r J$ dan D H karena jumlah paket beras dan harganya sudah ditentukan oleh $S d r J$

7 Keputusan Dirjen Penanganan Fakir Miskin Kemensos Nomor: 20/4/SK/HK.01/05/2018 tanggal 31 Mei 2018 tentang Perubahan Keempat Tahap Penyaluran Bantuan Sosial Beras Sejahtera dan Bantuan Pangan Non Tunai Tahun 2018

8 Surat Dirjen Penanganan Fakir Miskin Kemensos Nomor: 1281/PFM/PFM/ BS.02.01/08/2018 tanggal 27 Agustus 2018 Hal. Perluasan BPNT bulan Oktober 2018

9 Keputusan Menteri Sosial RI Nomor: 185/HUK/2018 tanggal 28 Desember 2018 tentang Penetapan Jumlah KPM dan Alokasi BPNT Tahun 2019

10 Keputusan Dirjen Penanganan Fakir Miskin Kemensos Nomor: 13A/4/SK/HK. 02.02/10/2019 tanggal 1 Oktober 2019 tentang Perubahan Jumlah KPM BPNT di 458 Daerah Kab./Kota Tahun 2019 
dan DH. Karena dikendalikan oleh Sdr J dan DH (PEPADI) maka para Suppliyer beras pembagiannya ke E-Warong dikendalikan oleh Sdr J (PEPADI), E-Warong tidak langsung mengambil ke Suppliyer namun melalui ke PEPADI. Bahwa sebenarnya e-Warong dapat langsung bekerja sama dengan para pedagang beras maupun penggilingan padi di Kab. setempat yang banyak tersebar di Kab. Setempat termasuk dengan pedagang telur. Namun karena proses sosialisasi e-Warong melibatkan PEPADI maka e-Warong tidak ada pilihan lain selain bekerja sama dengan PEPADI untuk suplay beras dan telurnya.

Bahwa masuknya PEPADI dalam Suplay beras pada program BPNT di Kab. setempat diduga difasilitasi Drs. D Myang saat itu menjabat sebagai Supervisor BPNT Dinsos PPKB Kab. setempat melalui sosialisasi kepada E-Warong yang mengarahkan agar mengambil barang berupa beras dan telur dari PEPADI.

Terhadap para supliyer beras tersebut selain harga yang telah ditentukan juga diharuskan mengemas beras dalam satuan karung $9 \mathrm{Kg}$ (untuk karung telah disediakan oleh sdr. DH. Sedangan untuk telur, sdr. D H mengambil dari supaliyer di Blitar Jawa Timur. Selama Periode Oktober 2018 s.d September 2019, KPM dalam pelaksanaan program BPNT di Kab. setempat memperoleh barang yang telah dipaketkan berupa beras $9 \mathrm{Kg}$ dan telur 7-12 butir (menyesuaikan harga beras dan telur) dengan harga total langsung sebesar Rp.110.000,00;

Sedangkan e-Warong ternyata hanya dijadikan sebagai tempat penitipan barang dan pembagian barang, dengan kompensasi yang telah ditetapkan oleh sdr. J dan DH yaitu sebesar Rp.5.000,00 per-KPM (paket).Sehingga ketika KPM telah menggesek kartunya dan dana telah tertransfer ke rekening e-Warong (pemilik EDC) sebanyak Rp.110.000,00, maka nilai yang sebesar Rp.105.000,00 akan disetorkan kepada sdr. J dan DH baik secara tunai maupun transfer ke rekening atas nama PEPADI. Hasil pembayaran dari e-Warong tersebut yang akan dibuat membayar beras kepada para supliyer beras maupun telur.

Akibat dari masuknya PEPADI dan abainya Dinas Sosial dan BNI dalam penyaluran BPNT di Kab. setempat tersebut, e-Warong yang diharapkan dapat berkembang ternyata tidak dapat mengembangkan diri karena tidak ada akses selain ke PEPADI, sedangkan PEPADI menjadi pihak yang paling banyak menerima keuntungan dari program BPNT di Kab. setempat."

Perspektif yuridis sosiologis peristiwa hukum di atas, diidentifikasi peneliti dalam menggali permasalahan penerapan BPNT, memuat beberapa temuan diantaranya: problem tiadanya sosialisasi yang memadai dari struktur sosial pelaksana dalam program BPNT, yakni Bank Penyalur dan Dinsos Kabupaten merupakan pra kondisi terjadinya kondisi anomie (Normlessness). Indikasi terlihat dari kebingungan pemilik e-Warong dalam mengakses pengetahuan pemasok bahan pangan sesuai peraturan atau norma dalam kebijakan BPNT. Keadaan anomie ini, menarik kondisi atau peristiwa hokum lainnya yang dapat disebut sebagai faktor korelatif kriminogen. Perubahan struktur sosial yang sedemikian rupa sehingga menghentak struktur budaya masyarakat, faktanya direspons oleh grassroot actor yang bermain dalam "perbuatan tercela". Deviasi tindakan yang berbau kolusi dengan pihak regulasi program, menjadi bentukan wujud peristiwa berikutnya. Pemanfaatan kesempatan bagi struktur social di masyarakat yang diuntungkan oleh keadaan anomie, terbuka lebar dalam menjalankan aksinya lebih jauh. Yaitu menyimpangkan tujuan program yang seharusnya (nilai atau value) bermanfaat bagi masyarakat secara adil, efisien dan berekonomi inklusif menjadi jauh dari cita hokum semula. 
Problematika yang dirumuskan dalam makalah ini adalah bagaimanakah potensi timbulnya tindak pidana korupsi penyimpangan program BPNT bersumber dari sosiologis penerapan program di masyarakat yang berlatar kondisi anomie?

Terdapat dua kata kunci dalam rumusan masalah tersebut:

Pertama adalah penyimpangan kebijakan program BPNT, yang disebabkan oleh causa sosiologis berupa relasi kuasa diantara aktor akar rumput (Grassroot Actor) terhadap akses kekuasaan pengadaan bahan pangan.

Kedua ialah imperative sosiologis terhadap potensi tindak pidana korupsi pada penyimpangan kebijakan BPNT.

Ketiga, kondisi anomie dalam sosiologis masyarakat yang menjadi lanskap perbuatan menyimpang karena tiadanya norma hukum yang menjadi patokan atau pegangan masyarakat.

Pokok permasalahan yang pertama, secara kerangka teori didekati dengan pandangan Ribot dan Peluso (2003). Sedangkan pokok masalah yang kedua akan dijelaskan melalui pandangan Robert Klitgaard tentang Penuntun Pemberantasan Tindak Pidana Korupsi di Pemerintahan Daerah (2005). Selain itu pada lanskap keadaan anomie, penulis menghadirkan teori atau konsep anomie Emile Durkiem (1893) dan diterangkan lebih lanjut oleh Robert K.Merton (1938).

1. Penaksiran Literatur dan Ide

a. Anomie dan Perubahan Sosial

Pandangan dalam sosiologi klasik, menyumbangkan istilah penting dalam memetakan kondisi atau keadaan masyarakat sehubungan dengan perubahan sosial dalam masyarakat tersebut. Anomie bercirikan keadaan tiadanya pegangan dan nilai, guna memahami kondisi dan perubahan yang sedang terjadi ( Normlessness $)^{11}$. Emile Durkeim berpandangan bahwa berbasis pada lanskap masyarakat Prancis paska revolusi industri (abad 19) menunjukan beberapa kondisi sosial yang berkarakter seperti: hilangnya status sosial masyarakat, akibat tekanan berat karena runtuhnya norma-norma sosial yang sebelumnya menjadi pegangan dan norma hidup masyarakat. Hilang keberadaannya dan sulit untuk memahami perubahan social yang terjadi, situasi yang sama sekali baru dan sulit dipahami. Durkeim percaya bahwa kondisi tersebut mampu memicu perbuatan menyimpang, diantaranya adalah bunuh diri (anomic suicide).

Lain halnya dengan Robert K.Merton, berlatar kondisi masyarakat Amerika tahun 1938 menerangkan bahwa ketidaksesuaian atau timbulnya diskrepansi atau perbedaan antara tujuan dalam budaya masyarakat ( cultural goals) dengan peralatan institusional/sosial (Institutional Means) dalam mencapai tujuan tersebut. Sebagai akibat dari struktur masyarakat yang terbagi atas pembagian kelas dalam masyarakat. Dinamika masyarakat dalam mencapai tujuan (social goals) yang membutuhkan sarana-sarana yang ada (acceptable means) merupakan topik temuan Robert K. Merton dalam penemuan teori anomie. Dia melihat bahwa tidak semua orang/warga masyarakat menggunaan sarana yang legal, dalam mencapai tujuan sosialnya. Untuk itu muncullah gejala penyimpangan sosial (terhadap norma atau

11 Rusydi Syahra, “Anomie Di Tengah Perubahan Sosial," Masyarakat Dan Budaya 3, no. 1 (2000): 4. 
nilai masyarakat) dalam kondisi anomie. Dengan bahasa sederhana Robert K. Merton, mendifinisikan penyimpangan atau deviasi dalam anomie sebagai hasil dari ketidakseimbangan ekonomi dan kesenjangan dari persamaan memperoleh kesempatan dalam masyarakat.

Inti gagasan dari mereka, baik Durkeim maupun Merton, setiap terjadi perubahan struktur sosial yang berhadapan dengan struktur budaya masyarakat menciptakan kondisi anomie, bercirikan normlessness, pada ujungnya memunculkan deviasi atau penyimpangan sosial masyarakat.

Pada konteks kajian penulis, mengenai pelaksanaan BPNT kondisi anomie terumusan dalam pra kondisi tiadanya sosialisasi program kepada e- warong. Mengakibatkan kebingungan pemilik e-warong dalam mengadaptasi sesuai norma yang berlaku yaitu apa syarat dan ketentuan pemilihan suppliyer bahan pangan. Dampak dari situasi anomie ini berujung kepada deviasi atau penyimpangan berikutnya dari gagasan program BPNT semula.

b. Kelompok Kepentingan dan Relasi Kuasa Terhadap Sumber Daya

Dalil argumentasi Ribot \& Peluso (2003), dalam mendeskripsikan kelompok kepentingan dan relasi kuasa terhadap sumber daya sebagai berikut: ${ }^{12}$

1) Relasi kuasa diantara aktor berkaitan dengan kekuasaan aktor untukmengontrol, memperoleh, dan mempertahankan aksesnya terhadap sumber daya.

2) Analisis relasi kuasa berlandaskan pada kekuasaan di dalam konteks politik ekonomi yang dapat membentuk kemampuan orang (kekuasaan aktor) dalam memanfaatkan sumber daya.

3) Definisi akses sebagai bundle dan jaring kekuasaan yang memungkinkan actor mendapatkan, mengendalikan, dan memelihara akses. Akses dapat diartikan sebagai suatu kemampuan untuk memperoleh keuntungan dari sesuatu. Misalnya, kemampuan untuk mendapatkan keuntungan dari objek material, orang, lembaga, dan simbol.

4) Kemampuan tersebut berkaitan dengan kekuasaan, di mana kekuasaan melekat dan dilaksanakan melalui berbagai mekanisme, proses, dan relasi sosial, modal, pasar, penguasaan teknologi, tenaga kerja, dan peluang kerja, pengetahuan, kewenangan, identitas sosial, dan relasi sosial (bundle of power) akan memengaruhi tingkat akses terhadap pemanfaatan dan pengelolaan sumber daya.

c. $\mathrm{C}=(\mathrm{D}+\mathrm{M})-\mathrm{A}$

Corruption (C) atau Korupsi sama dengan monopoly power (M, kekuasaan monopoli) plus discretion by officials (D, wewenang pejabat) minus accountability (A, akuntabilitas).

Rumus ini adalah kiasan dengan berbagai arti, salah satunya unsur tambah dan kurang.

Korupsi adalah fungsi dari berbagai faktor, dengan derivative parsial positif

12 Jesse C. Ribot and Nancy Lee Peluso, “A Theory of Access," Rural Sociology 68, no. 2 (2003): 153-81. 
dalam hal tingkat monopoli dan luas wewenang pejabat, dan derivative negative dalam hal akuntabilitas. Karena masing-masing variabel ini bersifat multi dimensi dank arena tidak ada ukuran yang dapat dipercaya seratus persen, rumus matematis ini tidak lebih dari sekadar alat bantu belajar.

Robert Klitgaard dalam mendalilkan pendekatan CDMA ini memberikan ukuran atau batasan sebagai berikut :

1) Jika seseorang memegang monopoli atas barang atau jasa dan memiliki wewenang untuk memutuskan siapa yang berhak mendapatkan barang atau jasa itu dan seberapa banyak.

2) Sementara itu tidak ada akuntabilitas, artinya orang lain dapat menyaksikan apa yang diputuskan oleh orang yang memegang wewenang itu.

Asas akuntabilitas, berorientasi pada hasil adalah asas yang menentukan bahwa setiap kegiatan dan hasil akhir dari kegiatan pengelolaan keuangan negara harus dapat dipertanggungjawabkan kepada rakyat sebagai pemegang kedaulatan tertinggi negara sesuai dengan ketentuan peraturan perundang-undangan yang berlaku.

2. Interpretasi Hasil Kajian

Nilai inti dalam filosofis hukum adalah salah satunya nilai keadilan. Nilai utama dalam lensa yuridis hukum adalah kepastian. Nilai primer dari sosiologis hukum adalah kegunaan atau manfaat. Setiap kebijakan apapun yang dirumuskan oleh pemerintah seyogyanya dipenuhi semua hal tersebut : nilai filosofis, nilai yuridis dan nilai sosiologisnya. Dalam konteks kebijakan program BPNT, ada baiknya untuk kita bahas mengenai keutuhan sistem kebijakan BPNT dalam perspektif hukum, yaitu perspektif filosofis, yuridis dan sosiologis.

Perspektif filosofis mengandung tata nilai keadilan. Bagaimana deskripsi filosofis program BPNT? Pada pertimbangan dasar hukum pelaksanaan kebijakan BPNT disebutkan bahwa ada dua pilar utama dalam aspek filosofisnya yaitu program BPNT berasaskan efisiensi berkeadilan dan ekonomi inklusif. Jika kita tinjau lebih dalam lagi terlihat bahwa kedua pilar itu (efisiensi berkeadilan dan ekonomi inklusif) memiliki pola yang sama. Yaitu program BPNT seharusnya (cita hukum ideal) terjadi distribusi ekonomi yang merupakan hak masyarakat,diterima tanpa melihat status sosial ekonominya. Efisiensi merupakan istilah ekonomi yang berarti penggunaan sumber daya seminimal mungkin guna menghasilkan manfaat sebesar mungkin bagi masyarakat. Paparan ini menunjukan bahwa dalam dimensi ekonomi penggunaan sarana ukuran efisiensi sebagai nilai yang seharusnya dalam mendistribusikan keadilan ekonomi bagi masyarakat. Alat atau sarana penanaman nilai keadilan itu melalui instrument ekonomi bernama ekonomi inklusif yang menjamin penerima manfaat dalam 6T yaitu tepat sasaran, waktu, kualitas, jumlah, harga dan administrasi. Ide utama ekonomi inklusif adalah pelibatan masyarakat dalam sistem keuangan modern, salah satunya menggunakan instrument perbankan. Jadi nilai filososfis BPNT terletak pada tekanan kata keadilan dan efisiensi. Pertimbangan pertama keadilan, lebih dulu baru bicara efisiensi. Pertimbangan pemenuhan hak masyarakat dulu, baru diikuti dengan tata penyaluran yang efisien. Salah satunya menggunakan instrument perbankan. 
Perspektif yuridis BPNT, menampilkan tata nilai kepastian hukum bahwa masyarakat yang berhak dan tepat sasaran dalam mendapatkan bantuan pangan. Istilah teknis dalam program BPNT, disebut dengan Keluarga Penerima Manfaat (KPM). Pada skema kebijakan BPNT, terlihat bahwa kepastian jaminan ini didasarkan pada induk data KPM yang terlembaga pada Kementrian Sosial. Berbasis kepada Pedoman Umum Pelaksanaan BPNT 2019, terumuskan disitu bahwa kerangka yuridis program BPNT meliputi latar belakang, ruang lingkup, mekanisme pelaksanaan, pengendalian dan kelembagaan. Tata kelola kebijakan ini menandakan bahwa sistematika kebijakan melalui institusi pemerintahan baik pusat maupun daerah.

Perspektif sosiologis program berbasis kepada sisi pemenuhan manfaat sebagai outcome program. Yaitu bantuan sosial berupa pangan secara nontunai kepada KPM. Kepastian manfaat yang diterima dikelola dengan menerapkan manajemen $6 \mathrm{~T}$ yaitu ketepatan dalam sasaran (KPM), harga, waktu, kualitas, kuantitas dan administrasi. Sistem keuangan inklusif memfasilitasi agar program sesuai dengan prinsip 6T tersebut. Peta transparansi dapat dimonitoring dan evaluasi secara terukur karena penggunaan data berbasis Information Technology. Intinya manfaat dapat segera diketahui karena KPM terindikasi telah menerima bantuan non tunai.

Fakta hukum yang terumuskan dalam teks kebijakan program BPNT, secara sederhana dapat dihimpun sebagai berikut :

a. Dimensi filosofis berlandaskan pada asas efisiensi berkeadilan. Original intensnya ada pada UUD 1945, Pasal 33 Ayat (4). Pedomannya adalah sumber daya seminimal mungkin untuk mencapai kemakmuran sebesar-besarnya yang dapat dinikmati secara merata oleh seluruh rakyat.

b. Dimensi yuridis meliputi 8 peraturan perundang-undangan, dari Peraturan Presiden hingga Peraturan Menteri. Kerangka hukum kebijakan ini mengatur tentang penyaluran bantuan sosial secara nontunai (Perpres No 63/2017), Strategi Nasional Keuangan Inklusif(Perpres No 82/2016), Belanja Bantuan Sosial pada Kementerian Negara/Lembaga (PMK No 254 /PMK.05/2015), Perubahan atas Peraturan Menteri Keuangan No 254/PMK.05/2015 tentang Belanja Bantuan Sosial pada Kementerian Negara/Lembaga (PMK No 228/PMK.05/2016 ), Pedoman Sistem Pengelolaan Pengaduan Pelayanan Publik Secara Nasional (Permen PAN Nomor 62 /2018 ), Program Keluarga Harapan (Permensos No 1 / 2018 ), Penyaluran Bantuan Pangan Nontunai (Permensos No 11 / 2018 ) dan

Pengelolaan Data Terpadu Kesejahteraan Sosial (Permensos No 5 / 2019). Peraturan tersebut dirancang sedemikian sehingga kepastian hukum bagi penerima bantuan pangan non tunai (KPM) terjamin.

c. Dimensi sosiologis: outcome atau hasil dari program BPNT benar-benar bermanfaat sesuai dengan prinsip 6T, yaitu tepat sasaran, harga, waktu, jumlah, kualitas dan administrasi. Selain itu terjadi peningkatan gairah ekonomi inklusif melalui partisipasi masyarakat dalam sistem perbankan modern.

Problematika BPNT, ternyata bukan terletak pada landasan filosofis, yuridis dan sosiologisnya. Sebagai sebuah kebijakan "baik" karena tata kelola sistemnya telah tuntas dalam telaah diketiga dimensi. Namun fakta sosiologis masyarakat pada saat pelaksanaan program terjadi beberapa anomaly. 
Penyebab penyimpangan pelaksanaan BPNT (kasus a quo), dalam perspektif sosiologis adalah (1) prakondisi minimnya proaktivitas Dinsos dan Bank Penyalur dalam sosialisasi program BPNT yang melibatkan E-Warong. Akibatnya terjadi "kebingungan" pemilik e-warong dalam penyediaan (supplier) bahan pangan. (2) Timbulnya celah kesempatan sehubungan dengan keadaan Anomie. (3) Grass Root Actor memanfaatkan kondisi anomie dalam rangkaian penyimpangan program BPNT dengan tujuan menguntungkan diri sendiri maupun kelompoknya.

BPNT, merupakan program baru yang meletakan kebijakan penyaluran bahan pangan non tunai kepada KPM. Analoginya sebuah bangunan struktur social baru yang berlandaskan pada peningkatan ekonomi inklusif masyarakat. Artinya program ini mengenalkan sistem perbankan kepada budaya masyarakat yang belum literer ("melek") dengan sistem bank. Sudah sewajarnya jika infrastruktur baru (Dinsos dan Bank Penyalur) lebih aktif dalam membangun subsistem ekonomi inklusif yang melibatkan e-Warong. Tugas utama e-Warong merupakan kepanjangan tangan dari bank penyalur. Fungsi utamanya adalah menyediakan bahan pangan berupa beras dan atau telur yang ditukar dengan bantuan non-tunai dari pemerintah kepada KPM. Budaya baru melalui implementasi BPNT ini, merupakan keniscayaan dari pemangku kepentingan terdekat dengan e-Warong yaitu Dinsos dan Bank Penyalur BPNT, lebih proaktif mengedukasi e-warong agar sesuai dengan pedoman umum dan petunjuk teknis pelaksanaan BPNT. Faktanya, terjadi keterbatasan sosialisasi bagi e-warong, sehingga menyiapkan kondisi atau prakondisi ketidakpastian atau kekurangjelasan terhadap syarat dan ketentuan dalam operasionalisasi e-warong bagi pemiliknya.

Ketidakpastian pengetahuan tentang peran dan fungsi e-warong menimbulkan ketiadaan norma (normlessness ) bagi pemilik e-warong sebagai subkultur baru dalam BPNT. Kondisi yang membingungkan bagi pemilik, sesuai dengan kondisi anomie bagi pemilik e-warong. Dalam hal tata cara mendatangkan supplier bahan pangan, pemilik e-warong gagap dan gagu karena tiadanya wawasan dan pengetahuan tentang hal itu. Perbuatan abai oleh regulator sistem yang telah mapan ( Dinsos dan Bank penyalur) berdampak kepada pemicu tindakan penyimpangan atau deviasi dalam keterhubungan subsistem dalam pelaksanaan BPNT selanjutnya.

Faktor korelatif kriminogen, terbuka lebar dan bagi aktor-aktor sosial yang mempunyai kesempatan atau peluang memanfaatkan karena faktor relasi kuasa menjadi pemain utama dalam permainan tercela. Pendekatan awal aktor akar rumput dalam stratifikasi sosial di masyarakat telah berindikasi kolusi dengan supervisor program. Hanya melalui aktor akar rumput ini saja, persediaan pasokan (inventory) bahan pangan ke e-warong dikendalikan dan dikuasai secara bersama-sama dengan kelompoknya saja.

Penyimpangan dalam perspektif sosiologis terlihat sebagai berikut :

a. "Saya mengetahui mengenai program BPNT tersebut, karena selain sebagai Kepala Desa saya juga sebagai Ketua Paguyuban Kepala Desa, selain juga sebagai pengurus PABDESI (Persatuan Aparatur Pemerintahan Desa Seluruh Indonesia) DPD Jawa Tengah sebagai Wakil Ketua, ...." 
b. "Sebenarnya e-Warong itu bebas mengambil supliyer beras maupun telur dari mana saja, namun untuk di R, sampai dengan September 2019 untuk beras BPNT disuplay oleh PEPADI dan telur BPNT saya dan Bu Wyang mensuplay."

Fakta sosiologis tersebut menggambarkan bahwa ada indikasi penyimpangan tujuan BPNT yang berbasis pada pilihan dan kendali bagi KPM, serta kebebasan E-Warong dalam memenuhi pasokan bahan pangan dari sumber lebih dari satu. Keterangan di atas menguatkan dalil bahwa proses monopoli pasokan bahan pangan ke E-Warong bermasalah. Kedua terjadi insuniasi perbuatan pemasok tunggal ke EWarong terindikasi tindak pidana korupsi.

Bukti bahwa fakta sosiologis mampu bertransformasi menjadi fakta hukum yang berujung pada tindak pidana korupsi, dapat diuraikan penulis sebagai berikut:

a. Ribot \& Peluso, berargumen dalam kelompok kepentingan dan relasi kuasa terhadap sumber daya, dengan tesis bahwa "kekuasaan melekat dan dilaksanakan melalui berbagai mekanisme, proses, dan relasi sosial, modal, pasar, penguasaan teknologi, tenaga kerja, dan peluang kerja, pengetahuan, kewenangan, identitas sosial, dan relasi sosial (bundle of power) akan memengaruhi tingkat akses terhadap pemanfaatan dan pengelolaan sumber daya."

b. Robert Klitgaard, berargumen bahwa: "Corruption (C) atau Korupsi sama dengan monopoly power (M, kekuasaan monopoli) plus discretion by officials (D, wewenang pejabat) minus accountability (A, akuntabilitas)."

Keterangan tersebut bermakna bahwa perubahan fakta sosiologis, yang melahirkan istilah aktor akar rumput (grassroot actor) dalam fenomena relasi kekuasan terhadap akses sumber daya. Karena adanya excessive power yang dimiliki oleh aktor tersebut maka dia mendapatkan akses tunggal (monopoli) terhadap rantai pasokan bahan pangan ke E-Warong. Bagaimana excessive power bekerja dalam perspektif sosial? Pada kasus penyimpangan program BPNT ini, aktor bermain peran di dua kaki, sebagai Kepala Desa (Peran Pemerintahan) dan sebagai Ketua PEPADI (Peran Pengusaha). Lebih dalam lagi nuansa kolusinya ketika bertransaksi dengan peran pengawas (Supervisor Program). Konflik kepentingan antar pihak, tidak dapat terelakan karena kecocokan trade of (tawar menawar) para pihak maka tujuan BPNT dalam aras Kebijakan, menyimpang dari arah semula. Dengan kata lain, nilai keadilan bagi masyarakat yang mendapatkan manfaat program BPNT tertunda karena nilai ekonomi kroni ( relasi kuasa dan kelompok kepentingan ) lebih utama daripada nilai kemanusiaan.

Relasi kuasa yang menyelundup ke dalam pelaksanaan program BPNT, oleh rambu-rambu hukum saat ini dapat dijerat dengan tindak pidana korupsi.

Pendekatan Klitgaard, dalam melihat korupsi secara sistem memaparkan hal-hal sebagai berikut:

a. Jika suatu kebijakan, terindikasi adanya Monopoli kekuasaan, Diskresi pengambil keputusan dan minim adanya pertanggungjawaban secara terbuka (Akuntabilitas) maka kemungkinan besar terjadi potensi tindak pidana korupsi. 
b. Dengan memeriksa apakah terjadi monopoli kekuasaan? Fakta sosiologis mengatakan bahwa aktor akar rumput berhasil mendapatkan akses pengelolaan sumberdaya karena relasi kuasa yang berujung monopoli.

c. Pengujian berikutnya adalah apakah ada diskresi oleh pegawai? Sangat jelas keterangan sosiologis menemukan bahwa melalui supervisor program BPNT, aktor akar rumput 'bermain" dalam akses praktek monopoli.

Dengan demikian melalui dua pendekatan teori kelompok kepentingan dan relasi kuasa, serta teori CDMAnya Robert Klitgaard, kita dapat merangkum hubungan antara "aktor akar rumput" (fakta sosiologis) dengan potensi tindak pidana korupsi (fakta hukum atau kriminologisnya).

Penyimpangan program BPNT, terjadi karena excessive power " aktor akar rumput" melalui relasi kuasa dalam mendapatkan akses pasokan bahan pangan secara monopoli (fakta sosiologis). Pada bingkai pendekatan CDMA, Corruption $=($ Discretion + Monopoly)-Accountability, menemukan bahwa terjadi diskresi supervisor program dengan jalan memberikan akses jalan kepada aktor akar rumput dalam memonopoli pasokan bahan pangan ke E-Warong ( Fakta Hukum).

\section{Kesimpulan}

Kondisi anomie pemilik e-warong menjadi pintu pembuka potensi timbulnya tindak pidana korupsi. Sumber utama dari peran aktor akar rumput (grassroot actor) yang memiliki excessive power dalam relasi kuasa mendapatkan akses sumber daya BPNT ( pasokan tunggal bahan pangan ke E-Warong). Penguatan potensi tindak pidana korupsi dibooster oleh perilaku diskresi supervisor program dalam melicinkan jalan grassroot actor ke praktek monopoli jalur pasokan. Sementara itu, akuntabilitas sosiologis peristiwa tersebut sangat minim karena mengandalkan sesi laporan yang berasal dari pelaksana program di lapangan.

Jadi, fakta sosiologis yang ditandai dengan kondisi Normlessness, menjadi prakondisi , peran aktor akar rumput melalui jembatan relasi kuasa plus diskresi petugas lapangan, mampu menghasilkan fakta hukum baru yaitu potensi tindak pidana korupsi. Karena tindak pidana (criminal) korupsi mensyaratkan (salah satunya) unsur kerugian keuangan Negara. Dalam hal ini timbul potencial loss disebabkan oleh menggeliatnya ekonomi inklusif sebagai pelumas perekonomian nasional tertunda karena penyimpangan kebijakan yang pro rakyat ini.

\section{Daftar Pustaka}

\section{Buku}

Ribot, J.C dan N.L. Peluso, A theory of access, Rural Sociology, Vol. 68 No 2, 2003

Robert Klitgaard et.al, Penuntun Pemberantasan Korupsi dalam Pemerintahan Daerah, Yayasan Obor Indonesia, Jakarta, 2005

Sudarto. Hukum Dan Hukum Pidana. Bandung: Alumni, 1981. 


\section{Artikel/Jurnal}

Adhi Anugroho, Ratih Lestarini dan Tri Hayati, Analisis Yuridis terhadap Asas Efisiensi Berkeadilan Berdasarkan Pasal 33 ayat (4) UUD 1945 dalam Peraturan Perundangundangan di bidang Ketenagalistrikan, Jurnal Hukum \& Pembangunan 47 No. 2 , 2017

Eva Royandi, Arif Satria dan Saharuddin,Kelompok Kepentingan dan Relasi Kuasa dalam Pengelolaan Sumber Daya Laut Palabuhan ratu, Fakultas Ekologi Manusia, Institut Pertanian Bogor (IPB), 2018

Rusydi Syahra, Anomie di Tengah Perubahan Sosial, Masyarakat dan Budaya, Vol 3, No 1, 2000

\section{Peraturan Perundang-Undangan}

Undang-Undang Dasar Negara Republik Indonesia Tahun 1945

Peraturan Presiden Republik Indonesia No 82 Tahun 2016 Tentang Strategi Nasional Keuangan Inklusif

Peraturan Presiden Republik Indonesia No 63 Tahun 2017 Tentang Bantuan Sosial Secara Non Tunai

Peraturan Menteri Sosial Nomor 10 Tahun 2017 tentang Program Keluarga Harapan

Peraturan Menteri Sosial No 1 Tahun 2018 tentang Program Keluarga Harapan

Peraturan Menteri Sosial No 11 Tahun 2018 tentang Penyaluran Bantuan Pangan NonTunai

\section{Sumber lainnya}

Anjaeni, Rahma. "Kemenkeu Catat Realisasi Penyaluran BPNT Kartu Sembako Senilai Rp 14,16 Triliun," 2020. https://nasional.kontan.co.id/news/kemenkeu-catat-realisasipenyaluran-bpnt-kartu-sembako-senilai-rp-1416-triliun.

Santoso, Ferry. "Realisasi Penyaluran Bansos Rastra Turun," 2019. http://bulog.co.id/ berita/37/6932/10/1/2019/Realisasi-Penyaluran-Bansos-Rastra-Turun.html.

Tim Pengendali Pelaksanaan Penyaluran Bantuan Sosial Secara Non Tunai. Pedoman Umum Bantuan Pangan Nontunai 2019. Jakarta Pusat: Kementerian Koordinator Bidang Pembangunan Manusia dan Kebudayaan, 2019. https:/www.kemsos.go.id/uploads/ topics/15767284433221.pdf. 